\title{
Risk factors of acute respiratory distress syndrome after on-pump cardiac surgery in the INFLACOR cohort study
}

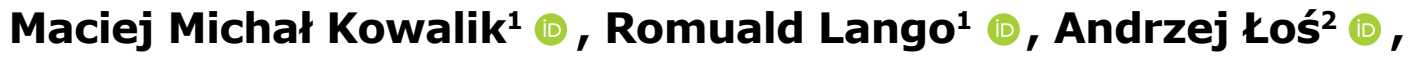

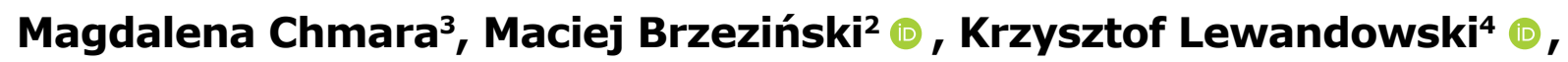 \\ Andrzej Klapkowski² ${ }^{\circledR}$, Jan Rogowski²
}

\begin{abstract}
${ }^{1}$ Department of Cardiac Anaesthesiology, Medical University of Gdańsk, Poland ${ }^{2}$ Department of Cardiac \& Vascular Surgery, Medical University of Gdańsk, Poland ${ }^{3}$ Department of Biology and Medical Genetics, Medical University of Gdańsk, Poland ${ }^{4}$ Department of Clinical Chemistry and Biochemistry, Medical University of Gdańsk, Poland
\end{abstract}

\begin{abstract}
Background: Acute respiratory distress syndrome (ARDS) is a serious complication after cardiac surgery with a variety of clinical risk factors. It was hypothesized that genome variants predispose these patients to it. Material and methods: A cohort of 509 adult Caucasians undergoing on-pump cardiac surgery were observed for postoperative ARDS defined by the Berlin definition. Clinical variables and 10 single-nucleotide variants of genes involved in inflammatory pathways were analyzed for associations with four groups, defined by paO2/fiO2 (PF) ratio: 1) no ARDS (PF > $300 \mathrm{mmHg}$ ), 2) mild ARDS ( $200<\mathrm{PF} \leq 300 \mathrm{~mm} \mathrm{Hg}$ ), 3) moderate ARDS (100<PF $\leq 200 \mathrm{~mm}$ $\mathrm{Hg}$ ), and 4) severe ARDS (PF $\leq 100 \mathrm{mmHg}$ ). Variables remaining in trends at $p<0.05$ were considered significant. Results: The prevalence of ARDS was $7.9 \%$. Only LBP rs 2232582 remained in a genotypic trend with ARDS aggravation $(p=0.08)$. Clinical variables associated with ARDS aggravation: impaired left ventricular ejection fraction $(p=0.04)$, pulmonary hypertension $(p=0.01)$, intraoperative hypotension $(p=0.009)$, and postoperative day 1 white blood cell count $(p=0.015)$. More aggravated ARDS was associated with longer mechanical ventilation $(p=0.01)$ and length of stay in ICU ( $p=0.002)$. Conclusions: The borderline association with LBP rs 2232582 and the identified risk factors suggest possible involvement of the LPS-LBP pathway in ARDS of the INFLACOR cohort.
\end{abstract}

Keywords: cardiac surgery $\cdot$ acute respiratory distress syndrome $\cdot$ cardiopulmonary bypass $\cdot$ LBP rs 2232582

\section{Citation}

Kowalik MM, Lango R, Łoś A, Chmara M, Brzeziński M, Lewandowski K, Klapkowski A, Rogowski J. Risk factors of acute respiratory distress syndrome after on-pump cardiac surgery in the INFLACOR cohort study. Eur J Transl Clin Med. 2020;3(1):24-33.

DOI: $10.31373 /$ ejtcm/122681

\footnotetext{
Corresponding author:
}

Maciej Michał Kowalik, Department of Cardiac Anaesthesiology, Medical University of Gdańsk, Poland

e-mail: mkowalik@gumed.edu.pl

Funded from grant NN40318181534.

Available online: www.ejtcm.gumed.edu.pl

Copyright ${ }^{\circledR}$ Medical University of Gdańsk

This is Open Access article distributed under the terms of the Creative Commons Attribution-ShareAlike 4.0 International. 


\section{Introduction}

Early postoperative morbidity after open-chest cardiac surgery is responsible for prolonged hospital stay, increased treatment costs and higher early mortality [1-5]. Postoperative respiratory failure (PRF) is considered one of the most important early postoperative complications after cardiac surgery [6].

In non-cardiac surgical patients, PRF defined as acute respiratory distress syndrome (ARDS) is most commonly associated with infection [7-8]. Whereas in cardiac surgical patients, inflammatory reactions triggered by the release of non-infectious antigens due to intraoperative gut and lung hypoperfusion during cardiopulmonary bypass (CPB), cell injury, blood contact with artificial surfaces, and blood product transfusion-related immune reactions are considered as the major pathological pathways which lead through massive cytokine release to postoperative ARDS and other organ dysfunction [9-11]. Mortality risk prediction models used in cardiac surgery, such as the EuroSCORE II model, were also shown to be effective in predicting specific postoperative morbidities, e.g. acure kidney injury (AKI) and PRF [12-13].

In addition to the identified clinical risk factors for postoperative morbidity, genome variants were considered to be useful in the prediction of specific postoperative complications after cardiac surgery [14-16]. Genetic association studies in cardiac surgical cohorts reported that single-nucleotide variants (SNVs) of the interleukin 6 (IL6), intercellular adhesion molecule 1 (ICAM1), E-selectin (SELE), C-reactive protein (CRP), and lipopolysaccharide binding protein (LBP) genes were associated with perioperative myocardial infarction (MI), AKI, bleeding, or cognitive impairment after coronary artery bypass graft surgery [17-21]. Other complications, such as bacteremia, AKI, and ARDS, were reported to be associated with SNVs of nucleotide-binding oligomerization domain-containing protein 2 (NOD2), toll-like receptor 4 (TLR4), mannose-binding protein-associated serine protease 2 (MASP2), nitric oxide synthase 3 (NOS3), and tumor necrosis factor (TNF) genes in non-cardiac surgical intensive care unit (ICU) patients [22-24].

The aim of this study was to test the hypothesis that selected SNVs of genes activated during the inflammatory response in humans may be associated with postoperative ARDS after on-pump cardiac surgery.

\section{Material and methods}

The prospective observational genetic association study INFLACOR (INFLammation After Cardiac OpeRation) was designed and conducted to evaluate the risk factors for 8 postoperative complications in patients undergoing open-heart cardiac surgery on cardiopulmonary bypass. The clinical variables, 4 selected cytokines and 10 SNVs were compared between patient groups. Adult Caucasian patients scheduled for open-heart surgery between October 22, 2009, and March 16, 2011, who signed informed consent were included. Patients scheduled for off-pump procedures, those with previous open-chest cardiac surgery and those who underwent emergency operations were excluded. The study protocol was approved by local Bioethics Commission (NKEBN/358/2007).

The primary outcome measure was a genotypic association between any of the selected SNVs and ARDS. The ten candidate SNVs were selected from previously published genotype-phenotype associations using the candidate gene approach: IL6 - rs1800796, LBP rs2232582, ICAM1 - rs5498, CRP - rs1800947, NOD2 rs2066844, TNF-rs1800629, MASP2 - rs2273346, SELE - rs1805193, NOS3 - rs1799983, TLR4 - rs4986790. The detailed genotyping method was published elsewhere [3]. ARDS was diagnosed following the so-called "Berlin definition" as the presence of bilateral lung infiltrates on chest X-ray (CXR) within 48 hours after operation combined with a mean $\mathrm{paO}_{2} / \mathrm{fiO}_{2}$ ratio $(\mathrm{PF}) \leq 300 \mathrm{~mm}$ $\mathrm{Hg}$ on mechanical ventilation and in absence of cardiogenic pulmonary edema [25]. The mean PF was calculated from all blood gas measurements performed on mechanical ventilation during the first postoperative day. Patients were assigned to one of four groups of disease severity according to the level of hypoxaemia: 1) no ARDS (PF > $300 \mathrm{mmHg}$ ), 2) mild ARDS ( $200<\mathrm{PF} \leq$ $300 \mathrm{~mm} \mathrm{Hg}$ ), 3) moderate ARDS (100<PF $\leq 200 \mathrm{~mm} \mathrm{Hg}$ ), and 4) severe ARDS (PF $\leq 100 \mathrm{mmHg}$ ). Secondary outcome measures included associations between 43 clinical candidate variables, including 17 pre-, 19 intra-, and 7 post-operative variables (Tables S1, S2, and S3 in the Supplementary Materials). Levels of interleukin 6 (IL-6), intercellular adhesion molecule 1 (ICAM1) and soluble E-selectin (sESEL) were measured in samples obtained three hours after admission to the postoperative ICU, centrifuged and cooled immediately, and stored in deep-freeze until being assayed with bead-based flow cytometry. The detailed processing protocol is published elsewhere [3]. Outcome data included total hours on ventilator (HOV), length of stay in ICU (LOS-ICU) and hospital (LOS-HOS), as well as 30-day and 5-year survival.

\section{Statistical methods}

The original cohort size calculations were based on the Kelsey formula with assumptions of $80 \%$ of power, 95\% two-sided confidence interval, and at SNP's exaggerating an effect with an odds ratio (OR) of at least 1.65. The $n=492$ was rounded up to $n=525$ for eventual loss of cases during the study. Genotypic association 
with the genotyped SNV was recognized by chi-square test for trend, when the wild-type and heterozygotic genotypes were correlated in a trend with ARDS severity, with a $p \leq 0.05$. Univariate analysis was used to identify the clinical risk factors for ARDS. Associations between continuous data were evaluated by either analysis of variance (ANOVA; A) or the Kruskal-Wallis (KW) test, depending on the data variance in Bartlett's test. Reported values for ANOVA or the KW tests are the mean and standard deviation (SD) or the median and interquartile range (IQR), respectively. Trends in the candidate variables between the ARDS groups with $p<0.05$ were considered significant. Epi-Info 7 (CDC, Atlanta, GA, USA; free license) and Statistica 12 (Statso$\mathrm{ft}$, Tulsa, OK, USA) software were used for the analyses.

\section{Results}

Clinical data, genotyping, and cytokine measurements were obtained from $n=525$ patients. Of them, $n=509$ (97.0\%) were included in the analyses. The patient flow and reasons for exclusion from analysis are presented in Figure 1.
Among the analyzed $n=509$ patients, $n=40$ (7.9\%) met the criteria for ARDS according to the Berlin definition. Lung parenchyma infiltrates on CXR were identified in $n=73$ (14.3\%) patients. Sustained hypoxemia, defined by a mean PF $\leq 300 \mathrm{~mm} \mathrm{Hg}$ on mechanical ventilation, was diagnosed in $n=301$ (59.1\%) patients. Simultaneous CXR lung opacities and hypoxemia were present with mild $(n=28,5.5 \%)$, moderate ( $n=11$, $2.2 \%)$ and severe ( $n=1,0.2 \%)$ intensity, which corresponded to $70 \%, 28 \%$, and $2 \%$ of the ARDS patients.

Another frequent CXR finding was lung congestion and atelectasis, which were found in $n=143(28.1 \%)$ and $\mathrm{n}=12(2.4 \%)$ patients respectively, however neither of them was associated with hypoxemia or ARDS worsening (tests for PF means and prevalence trends with $p>0.05$ ).

The primary outcome sought in this analysis was a genotypic association between any of the 10 genotyped SNVs of genes involved in the human inflammatory response and the aggravation of the ARDS phenotype. Only the LBP rs2232582 (19983 T > C) suggested a genotypic trend, with a $p=0.08$. Carriers of the recessive $C$ allele presented with lower risk for ARDS in an additive model. However, none of the tested genetic associations reached the assumed level of significance.

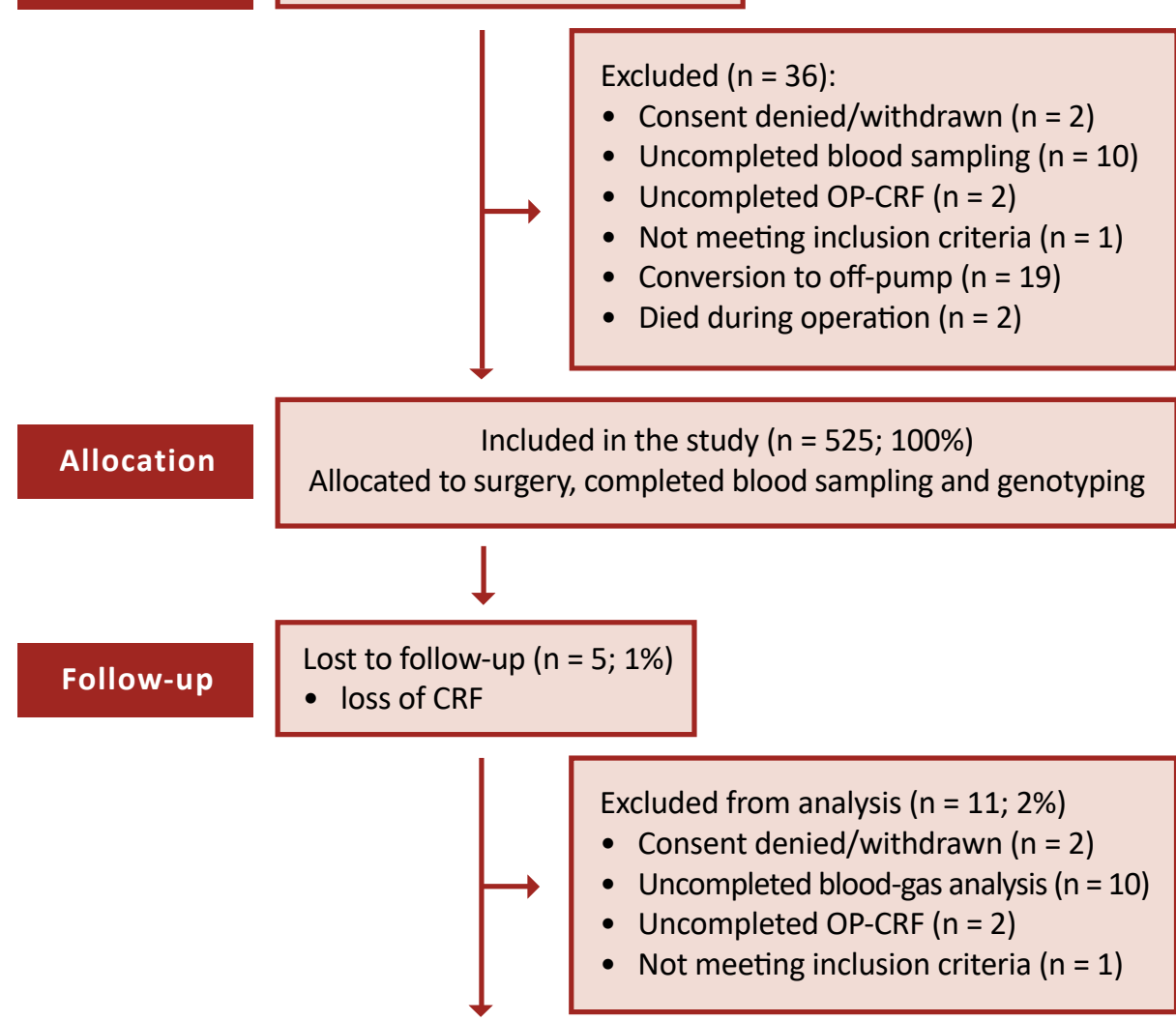




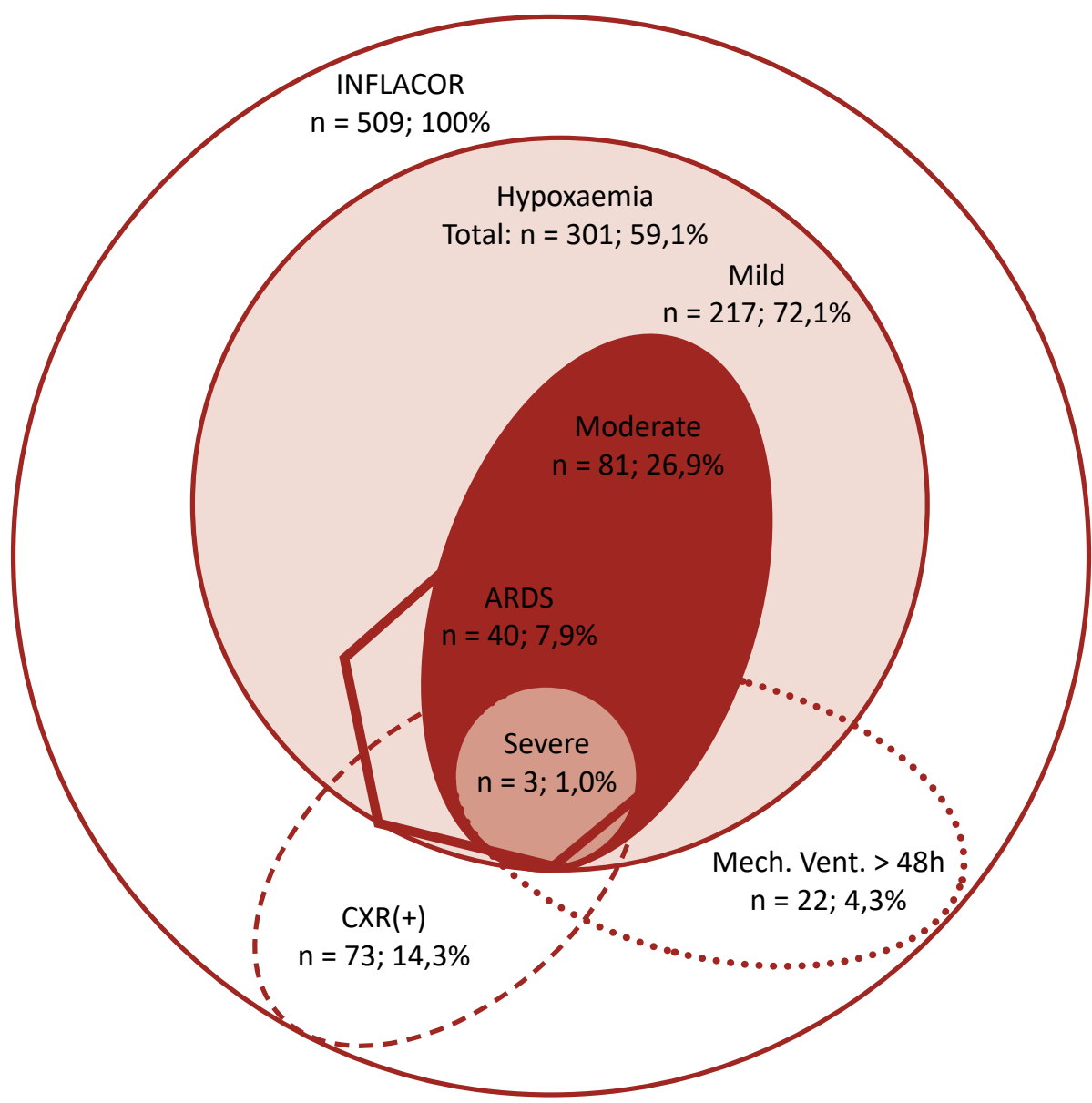

Figure 2. Prevalence of hypoxemia,

pulmonic opacities on chest X-ray, and prolonged mechanical ventilation in $\mathbf{n}=\mathbf{5 0 9}$ patients from the INFLACOR study

Forty patients were diagnosed with ARDS upon simultaneous presentation of lung opacities on chest X-ray and sustained hypoxemia defined by $\mathrm{pO}_{2} / \mathrm{fiO}_{2}(\mathrm{PF}) \leq 300$ on mechanical ventilation. Of the $n=40$ patients with ARDS $n=28(70 \%)$ presented with mild hypoxemia, $n=11(28 \%)$ with moderate hypoxemia, and $n=1(2 \%)$ with severe hypoxemia. Patients with ARDS made up $7.9 \%$ ( $n=40 / 509)$ of the whole analyzed cohort, $13.3 \%(n=40 / 301)$ of patients with hypoxemia, and $54.8 \%(n=40 / 73)$ of patients with a positive chest X-ray, but only $16.9 \%(n=10 / 59)$ of patients ventilated for longer than 24 hours and $13.6 \%(n=3 / 22)$ of patients ventilated mechanically for longer than 48 hours. The prevalence of hypoxemia, a positive chest $\mathrm{X}$-ray, and mechanical ventilation > 48 hours provided in the graph was calculated for the whole cohort of $n=509$ patients. The prevalence of hypoxemia levels (mild, moderate, and severe) is calculated for $n=301$ patients with hypoxaemia.

A list of four risk factors was identified from the clinical candidate variables. Of the 17 analyzed pre-operative candidate variables, only impaired left ventricular ejection fraction and pulmonary hypertension were associated, with a significant trend, with ARDS aggravation.

Supplementary Table 1. Analysis of trends between preoperative candidate variables and ARDS aggravation in $n=509$ patients from the INFLACOR cohort $\rightarrow$ go to: https://ejtcm.gumed.edu.pl/files/56

Six categories of surgical procedures were defined based on the type and complexity of the surgery. The prevalence of ARDS did not differ between the surgical groups.
Supplementary Table 2. Analysis of trends between intra-operative candidate variables and ARDS aggravation in $\mathbf{n}=\mathbf{5 0 9}$ patients from the INFLACOR cohort $\rightarrow$ go to: https://eitcm.gumed.edu.pl/files/57

Of the 14 intraoperative candidate variables, four dexamethasone dose and number of transfused units of packed red blood cells, fresh frozen plasma and platelets concentrate - were analyzed both as continuous variables and after conversion into categorical variables. Significant correlations with ARDS severity were identified only for the duration of intraoperative hypotension, defined as mean arterial pressure $<60 \mathrm{mmHg}$.

Of the seven analyzed postoperative variables only the white blood cell (WBC) count showed a si- 
Table 1. Analysis of genotypic trends between the single nucleotide variants of $\mathbf{1 0}$ genes involved into inflammatory response and ARDS aggravation in $n=509$ patients from the INFLACOR cohort

\begin{tabular}{|c|c|c|c|c|c|c|}
\hline No. & $\begin{array}{c}\text { ARDS } \\
\text { SNV, } \\
\text { Genotypes }\end{array}$ & $\begin{array}{c}(1) \\
n=469 \\
(92.1 \%)\end{array}$ & $\begin{array}{c}(2) \\
n=28 \\
(5.5 \%)\end{array}$ & $\begin{array}{c}(3) \\
n=11 \\
(2.2 \%)\end{array}$ & $\begin{array}{c}(4) \\
n=1 \\
(0.2 \%)\end{array}$ & $\begin{array}{c}\text { p-value } \\
\text { for } \\
\text { trend }\end{array}$ \\
\hline 1 & $\begin{array}{l}\text { IL6 rs1800796 } \\
\text { GG } \\
\text { CG } \\
\text { CC }\end{array}$ & $\begin{array}{c}420(89.6) \\
44(9.4) \\
5(1.1)\end{array}$ & $\begin{array}{c}23(82.1) \\
5(17.9) \\
0(0)\end{array}$ & $\begin{array}{c}9(81.8) \\
2(18.2) \\
0(0)\end{array}$ & $\begin{array}{c}1(100) \\
0(0) \\
0(0)\end{array}$ & $0.17^{1}$ \\
\hline $\begin{array}{c}\text { Sex } \\
2\end{array}$ & $\begin{array}{l}\angle B P \operatorname{rs} 23 / 3 / 2582 \\
\text { TT } \\
\text { CT } \\
\text { CC }\end{array}$ & $\begin{array}{c}4 / 6 \\
345(73.6) \\
111(23.7) \\
13(2.8)\end{array}$ & $\begin{array}{c}24(85.7) \\
4(14.3) \\
0(0.0)\end{array}$ & $\begin{array}{c}10(90.9) \\
1(9.1) \\
0(0)\end{array}$ & $\begin{array}{c}1(100) \\
0(0) \\
0(0)\end{array}$ & $0.08^{1}$ \\
\hline 3 & $\begin{array}{l}\text { ICAM1 rs5498 } \\
\text { AA } \\
\text { AG } \\
\text { GG }\end{array}$ & $\begin{array}{c}148(31.6) \\
237(50.5) \\
84(17.9)\end{array}$ & $\begin{array}{c}4(14.3) \\
18(64.3) \\
6(21.4)\end{array}$ & $\begin{array}{c}6(54.6) \\
4(36.4) \\
1(9.1)\end{array}$ & $\begin{array}{c}0(0) \\
1(100) \\
0(0)\end{array}$ & $\begin{array}{l}0.63^{1} \\
0.79^{2}\end{array}$ \\
\hline 4 & $\begin{array}{l}\text { CRP rs1800947 } \\
\text { GG } \\
\text { GC } \\
\text { CC }\end{array}$ & $\begin{array}{c}382(81.5) \\
87(18.6) \\
0(0)\end{array}$ & $\begin{array}{c}23(82.1) \\
5(17.9) \\
(0)\end{array}$ & $\begin{array}{c}10(90.9) \\
1(9.1) \\
(0)\end{array}$ & $\begin{array}{c}1(100) \\
0(0) \\
0(0)\end{array}$ & $0.42^{1}$ \\
\hline 5 & $\begin{array}{l}\text { NOD2 rs2066844 } \\
\text { CC } \\
\text { CT } \\
\text { TT }\end{array}$ & $\begin{array}{c}437(93.2) \\
32(6.8) \\
0(0)\end{array}$ & $\begin{array}{c}27(96.4) \\
1(3.6) \\
0(0)\end{array}$ & $\begin{array}{c}11(100) \\
0(0) \\
0(0)\end{array}$ & $\begin{array}{c}1(100) \\
0(0) \\
0(0)\end{array}$ & $0.26^{1}$ \\
\hline 6 & $\begin{array}{l}\text { TNF rs1800629 } \\
\text { GG } \\
\text { GA } \\
\text { AA }\end{array}$ & $\begin{array}{c}340(72.5) \\
121(25.8) \\
8(1.7)\end{array}$ & $\begin{array}{c}21(75.0) \\
7(25.0) \\
0(0)\end{array}$ & $\begin{array}{c}8(72.7) \\
3(27.3) \\
0(0)\end{array}$ & $\begin{array}{c}1(100) \\
0(0) \\
0(0)\end{array}$ & $0.82^{1}$ \\
\hline 7 & $\begin{array}{l}\text { MASP2 rs2273346 } \\
\text { TT } \\
\text { СT } \\
\text { CC }\end{array}$ & $\begin{array}{c}457(97.4) \\
12(2.6) \\
0(0)\end{array}$ & $\begin{array}{c}27(96.4) \\
1(3.6) \\
0(0)\end{array}$ & $\begin{array}{c}10(90.9) \\
1(9.1) \\
0(0)\end{array}$ & $\begin{array}{c}1(100) \\
0(0) \\
0(0)\end{array}$ & $0.28^{1}$ \\
\hline 8 & $\begin{array}{l}\text { SELE rs } 1805193 \\
\text { GG } \\
\text { GT } \\
\text { Tा }\end{array}$ & $\begin{array}{c}373(79.5) \\
90(19.2) \\
6(1.3)\end{array}$ & $\begin{array}{c}16(57.1) \\
10(35.7) \\
2(7.1)\end{array}$ & $\begin{array}{c}10(90.9) \\
1(9.1) \\
0(0)\end{array}$ & $\begin{array}{c}1(100) \\
0(0) \\
0(0)\end{array}$ & $\begin{array}{l}0.61^{1} \\
0.28^{2}\end{array}$ \\
\hline 9 & $\begin{array}{l}\text { NOS3 rs1799983 } \\
\text { GG } \\
\text { GT } \\
\text { TT }\end{array}$ & $\begin{array}{c}210(44.8) \\
211(45.0) \\
48(10.2)\end{array}$ & $\begin{array}{c}15(53.6) \\
9(32.1) \\
4(14.3)\end{array}$ & $\begin{array}{c}5(45.5) \\
6(54.6) \\
0(0)\end{array}$ & $\begin{array}{c}1(100) \\
0(0) \\
0(0)\end{array}$ & $\begin{array}{l}0.45^{1} \\
0.47^{2}\end{array}$ \\
\hline 10 & $\begin{array}{l}\text { TLR4 rs4986790 } \\
\text { AA } \\
\text { GA } \\
\text { GG }\end{array}$ & $\begin{array}{c}415(88.5) \\
53(11.3) \\
1(0.2)\end{array}$ & $\begin{array}{c}23(82.1) \\
5(17.9) \\
0(0)\end{array}$ & $\begin{array}{c}10(90.9) \\
1(9.1) \\
0(0)\end{array}$ & $\begin{array}{c}1(100) \\
0(0) \\
0(0)\end{array}$ & $0.76^{1}$ \\
\hline
\end{tabular}

${ }^{1} \mathrm{p}$-value for $\mathrm{X}^{2}$ for trend with the heterozygotic (1) or homozygotic recessive (2) genotype treated as risk variable; as none test reached the assumed significance level of $p \leq 0.05$, odds ratios are not provided;

ARDS - acute respiratory distress syndrome; letters: A, C, G, T - denominate respectively adenine, cytosine, guanine, thymine nucleotides in genotyped single nucleotide polymorphisms; CRP - C-reactive protein; ICAM1 - intercellular adhesion molecule 1; IL6 - interleukin 6; LBP - lipopolysaccharide binding protein; MASP2 - mannose-binding protein-associated serine protease 2; NOD2 - nucleotide-binding oligomerization domain-containing protein 2; NOS3 - nitric oxide synthase 3; SELE - E-selectin, TLR4 - toll-like receptor 4; TNF - tumor necrosis factor. 
gnificant trend with ARDS severity, though CRP and glucose level were close (both with a $p=0.08$ ).

Supplementary Table 3. Analysis of trends between postoperative candidate variables and ARDS aggravation in $\mathbf{n}=\mathbf{5 0 9}$ patients from the INFLACOR cohort $\rightarrow$ go to: https://ejtcm.gumed.edu.pl/files/58

\section{Outcome analysis}

The median time of mechanical ventilation in the whole cohort was 11.9 hours (IQR: $8.5-17.9$ ). Of the total of $n=509$ patients, $n=59(11.6 \%)$ and $n=22$ (4.3\%) were mechanically ventilated longer than 24 and 48 hours, respectively. Of the patients ventilated longer than 24 and 48 hours, ARDS was diagnosed in $n=10 / 59(16.9 \%)$ and $n=3 / 22(13.6 \%)$, respectively. Patients with more severe ARDS required more HOV and longer LOS-ICU.

\section{Discussion}

The INFLACOR study was primarily designed as a genetic association study, following projects such as the PEGASUS and FIFA trials $[3,17,19]$. The ability to genotype selected SNVs at the turn of the millennium led to the sound hypothesis that genetic tests could improve our prediction ability of the most devastating complications of on-pump cardiac surgery [15-16, 26]. Crucial for identification of any genetic association is

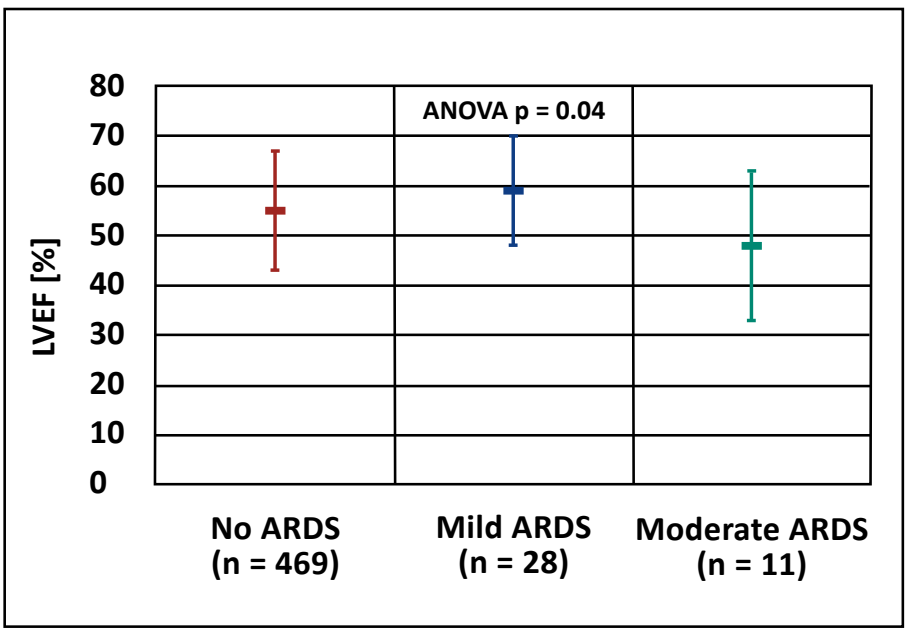

Panel A. Preoperative left ventricular ejection fraction

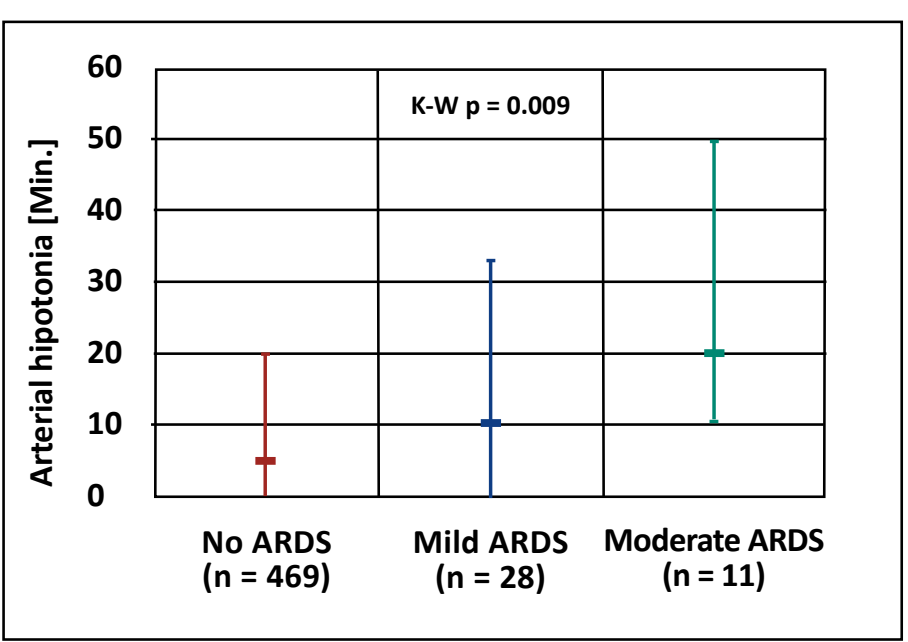

Panel C. Intraoperative arterial hypotension (MAP $\leq 60 \mathrm{mmHg}$ )

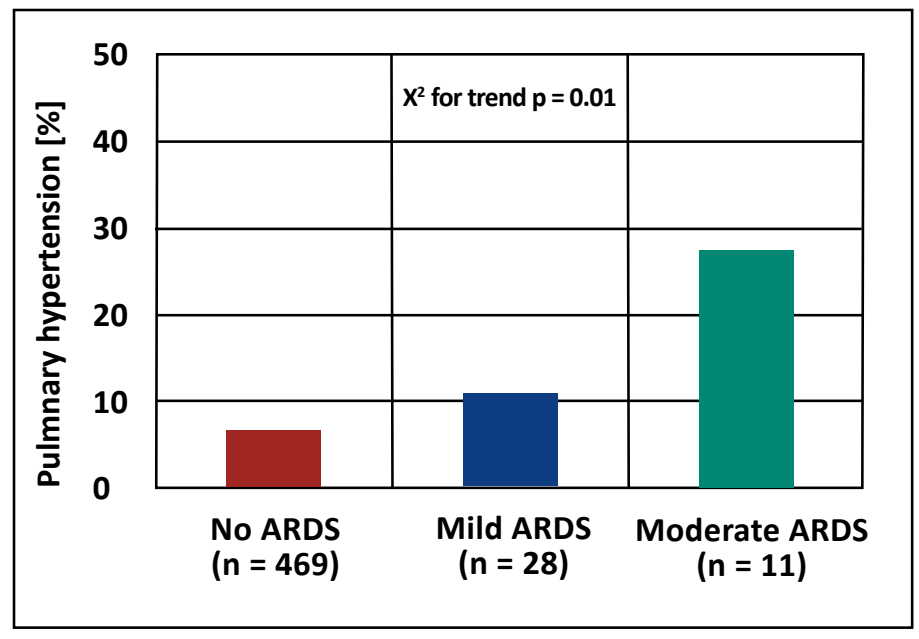

Panel B. Pulmonary hypertension

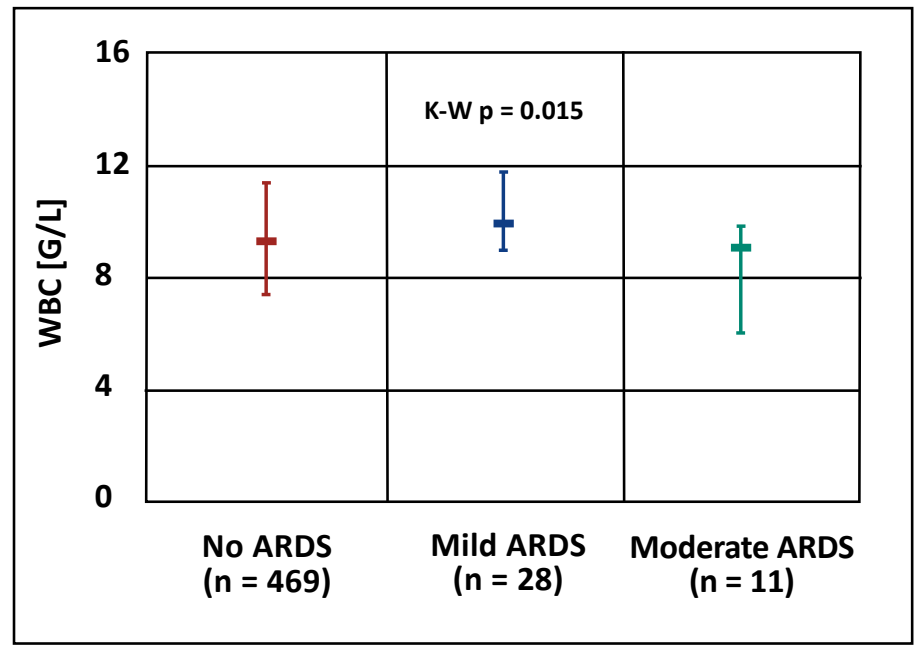

Panel D. Postoperative day 1 WBC

Figure 3. Perioperative variables associated with ARDS severity in the $\mathbf{n}=\mathbf{5 0 9}$ INFLACOR patients: left ventricular ejection fraction (LVEF; Panel A), pulmonary hypertension (Panel B), duration of intraoperative hypotension (Panel C), and postoperative day 1. white blood cell count (WBC; Panel D) 
Table 2. Outcome variables and ARDS aggravation in $n=509$ patients from the INFLACOR cohort

\begin{tabular}{|c|c|c|c|c|c|}
\hline Outcome & $\begin{array}{c}(1) \\
n=469 \\
(92.3 \%)\end{array}$ & $\begin{array}{c}(2) \\
n=28 \\
(5.5 \%)\end{array}$ & $\begin{array}{c}(3) \\
n=11 \\
(2.2 \%)\end{array}$ & $\begin{array}{c}(4) \\
n=1 \\
(0.2 \%)\end{array}$ & p-value \\
\hline $\begin{array}{l}\text { HOV [hours] } \\
\text { (median; IQR) }\end{array}$ & $11.9(8.5-17.5)$ & $10.3(7.9-14.8)$ & $19.4(15.7-21.8)$ & 42.6 & 0.01 \\
\hline $\begin{array}{l}\text { LOS-ICU [days] } \\
\text { (median; IQR) }\end{array}$ & $1.6(0.9-2.8)$ & $2.9(1.0-5.4)$ & $3.0(1.0-4.8)$ & 2.8 & 0.002 \\
\hline $\begin{array}{l}\text { LOS-HOS [days] } \\
\text { (median; IQR) }\end{array}$ & $8.0(7.0-11.0)$ & $9.0(7.0-13.0)$ & $10.0(7.0-10.0)$ & 10.0 & 0.82 \\
\hline 30-day mortality [\%] & 3.0 & 7.1 & 9.1 & 0 & 0.11 \\
\hline 5-year mortality [\%] & 22.6 & 32.1 & 18.2 & 0 & 0.67 \\
\hline
\end{tabular}

HOV - hours on ventilator, LOS - length of stay, ICU - intensive care unit, HOS - hospital

the precise definition and selection of the phenotypes used as outcome measures. The correct allocation into the true-positive and true-negative subgroups is the cornerstone of correct statistical results and appropriate clinical inference. In the INFLACOR study, the Berlin definition of ARDS was adopted to define the affected patients [25]. This definition defines the ARDS by the concomitant presence of pulmonary infiltrates on CXR and hypoxemia along with an absence of left ventricle failure. The Berlin definition introduces three, mutually exclusive, severity stages of the syndrome, based upon the severity of hypoxemia [25]. This continuum of disease aggravation was utilized for calculating trends for the analyzed variables in the current study. A significant association trend between a variable and ARDS aggravation was assumed to strengthen the inference over the identified risk factors. This methodology is relatively infrequent and novel in ARDS studies in cardiac surgical patients but is compatible with the recommendations from the Berlin conference on ARDS [25].

The primary outcome in this study was any genotypic association with ARDS. None of the ten tested SNVs breached the assumed significance level of a trend with ARDS severity. However, the carriers of the wild-type (T) allele in LBP rs2232582 presented a genotypic trend towards a higher incidence of more aggravated ARDS at a $p=0.08$. This novel finding requires confir- mation on a larger sample. The LBP rs2232582 was previously reported to be associated with postoperative $\mathrm{MI}$, also with $\mathrm{T}$ being the risk allele [17]. The protein encoded by the LBP gene, the lipopolysaccharide binding protein (LBP), is involved in the acute-phase immunologic response to gram-negative bacterial infections. Gram-negative bacteria contain a glycolipid, lipopolysaccharide (LPS), on their outer cell wall. Together with bactericidal permeability-increasing protein, LBP binds LPS and interacts with the CD14 receptor, probably playing a role in regulating LPS-dependent monocyte responses. LPS from Gram-negative bacteria have been shown to trigger experimental ARDS in an animal model [27]. The serum level of LBP has been associated with survival in patients with ARDS and sepsis [28]. Furthermore, the LBP rs2232582 is reported to have a significant association with highly active antiretroviral-associated lipodystrophy syndrome, progressively higher bacterial translocation, serum LPS, and LBP level [29]. LPS may translocate from the patient gut microbiota during prolonged hypothermia and/or gut hypoperfusion on CPB [9].

Shock was reported to be a risk factor for ARDS after cardiac surgery by Milot et al., which is consistent with prolonged intraoperative hypotension, the sole intraoperative risk factor in our study [30]. Inflammation was an important contributor to ARDS in the INFLACOR patients, as displayed by postoperative day 1 increase in WBC, CRP and glucose levels. 
Hence, the role of the LPS-LBP inflammatory pathway seems to be a probable dominant pathway of ARDS in the INFLACOR cohort. Thus, a pivotal role for LBP rs2232582 in the pathogenesis of ARDS seems possible and probable. Unfortunately, the INFLACOR patients were not tested neither for LPS, nor for the LBP levels in serum.

Despite the lack of significant genetic associations, this study identified four clinical risk factors of ARDS using the trend analysis. A recent review of clinical studies on ARDS in cardiac surgical patients revealed a great variability of clinical risk factors [31]. While some studies identified massive transfusion as a risk factors of TRALI-ARDS (a risk factor not confirmed in the present study), other studies reported impaired left ventricular ejection fraction and/or pulmonary hypertension [31-33]. Both were found to be risk factors also in the INFLACOR study.

In cardiac surgical cohorts, it is common to utilize only the duration of mechanical ventilation to define $\operatorname{PRF}[1,6,13,34]$. The rates of mechanical ventilation $>24$ hours of $11,3 \%$ observed in this study were similar to those in other cardiac surgical studies [4, 32-33]. The prevalence of ARDS among patients ventilated for longer than 24 hours of $16.9 \%$ and among patients ventilated for longer than 48 hours was $13.6 \%$, which may appear low. However, an epidemiological study by Rubenfeld in a cohort of 4251 non-cardiac surgical patients ventilated for longer than 24 hour diagnosed ARDS in only $26.2 \%$ [35]. Notably, interobserver variability in the interpretation of CXR with regard to ARDS diagnosis has been emphasized an important bias [36-37]. This factor might have also influenced the discrepancy between CXR(+)-patients and ARDS-patients in the current analyses. Furthermore, it was differentiated between pulmonary congestion and lung opacities. However, a systematic differentiation between cardiogenic lung edema and ARDS was not performed. Part of the analyzed cases presented with pulmonary hypertension and impaired LVEF, thus making a cardiogenic component of the ARDS even more probable. Unfortunately, the detailed data of postoperative echocardiographic examination or pulmonary artery wedge pressure, which would allow to discriminate the two conditions, were not recorded in the study.

ARDS resulted not only in longer mechanical ventilation but also in prolonged ICU stay. However, the whole stay in the surgical department did not differ between patients with and without ARDS, as well as 30-day and 5-year mortality were also not affected. This might be the result of analyzing data only until discharge from the cardiac surgical department and not until final hospital discharge.
This study failed to confirm a statistically significant association between the ARDS phenotype and selected SNVs due to the low incidence of ARDS in the relatively small analyzed cohort. Another important limitation of our study was the lack of systematic verification of CXR interpretations for bilateral opacities. The selection of mean PF on mechanical ventilation as the measure of ARDS severity, instead of the minimal PF, maximal PF, or first-day trends in the PF, may be disputable, but the average value was considered the most reliable parameter of sustained hypoxaemia. Another important limitation is the lack of systematic discrimination between cardiogenic pulmonary edema and ARDS. Finally, the lack of a replicative cohort is an important disadvantage of the present study, however its protocol was designed before the recommendations on genetic association studies were published [38].

\section{Conclusions}

The prevalence of ARDS among the adult patients undergoing cardiac surgery on cardiopulmonary bypass was $7.9 \%$. Identified clinical risk factors were: impaired left ventricular ejection fraction, pulmonary hypertension, intraoperative hypotension, and postoperative day 1 white blood cell count. A probable genotypic trend for $L B P$ rs2232582 suggests that the role of the LPS-LBP inflammatory pathway might have played a dominant role in the pathogenesis of ARDS in the INFLACOR cohort.

\section{Acknowledgements}

The authors express their gratitude to Prof. Janusz Limon MD, PhD (Deptartment of Biology and Genetics, Medical University of Gdańsk) for his invaluable support in conducting the INFLACOR trial and to Alexandra Biedrzycka, Monika Żuk, Małgorzata Smyl, Małgorzata Szydłowska-Czyżak, and the nursing staff of the postoperative ICU at the Department of Cardiac and Vascular Surgery for their contribution to the data collection, laboratory analyses and administrative support.

Funding: Grant NN403181534 "INFLACOR" 20092011 from the Polish Ministry of Science and Higher Education. The authors declare no conflicts of interest. The INFLACOR study protocol was registered in the Clinical Trial database (http: clinicaltrials.gov; NCT01020409). 


\section{References}

1. LaPar DJ, Crosby IK, Rich JB, Fonner E, Kron IL, Ailawadi G, et al. A Contemporary Cost Analysis of Postoperative Morbidity After Coronary Artery Bypass Grafting With and Without Concomitant Aortic Valve Replacement to Improve Patient Quality and Cost-Effective Care. Ann Thorac Surg [Internet]. 2013;96(5):1621-7. Available from: https://doi.org/10.1016/i. athoracsur.2013.05.050

2. LaPar DJ, Speir AM, Crosby IK, Fonner E, Brown M, Rich JB, et al. Postoperative Atrial Fibrillation Significantly Increases Mortality, Hospital Readmission, and Hospital Costs. Ann Thorac Surg [Internet]. 2014;98(2):527-33. Available from: https://doi.org/10.1016/i.athoracsur.2014.03.039

3. Kowalik MM, Lango R, Siondalski P, Chmara M, Brzeziński M, Lewandowski K, et al. Clinical, biochemical and genetic risk factors for 30-day and 5-year mortality in 518 adult patients subjected to cardiopulmonary bypass during cardiac surgery - the INFLACOR study. Acta Biochim Pol [Internet]. 2018;65(2):241-50. Available from: https://doi.org/10.18388/abp.2017 2361

4. Huen SC, Parikh CR. Predicting Acute Kidney Injury After Cardiac Surgery: A Systematic Review. Ann Thorac Surg [Internet]. 2012;93(1):337-47. Available from: https://doi.org/10.1016/i.athoracsur.2011.09.010

5. Brown CH. Delirium in the cardiac surgical ICU. Curr Opin Anaesthesiol [Internet]. 2014;27(2):117-22. Available from: https://doi.org/10.1097/aco.0000000000000061

6. Canver CC, Chanda J. Intraoperative and postoperative risk factors for respiratory failure after coronary bypass. Ann Thorac Surg [Internet]. 2003;75(3):853-7. Available from: https://doi.org/10.1016/S0003-4975(02)04493-4

7. Gajic O, Dabbagh O, Park PK, Adesanya A, Chang SY, Hou P, et al. Early Identification of Patients at Risk of Acute Lung Injury. Am J Respir Crit Care Med [Internet]. 2011;183(4):462-70. Available from: https://doi.org/10.1164/rccm.201004-05490C

8. Opitz B, van Laak V, Eitel J, Suttorp N. Innate Immune Recognition in Infectious and Noninfectious Diseases of the Lung. Am J Respir Crit Care Med [Internet]. 2010;181(12):1294-309. Available from: https://doi.org/10.1164/rC$\mathrm{cm} .200909-1427 \mathrm{SO}$

9. Warren OJ, Smith AJ, Alexiou C, Rogers PLB, Jawad N, Vincent C, et al. The Inflammatory Response to Cardiopulmonary Bypass: Part 1-Mechanisms of Pathogenesis. J Cardiothorac Vasc Anesth [Internet]. 2009;23(2):223-31. Available from: https://doi.org/10.1053/i.jvca.2008.08.007

10. Warltier DC, Laffey JG, Boylan JF, Cheng DCH. The Systemic Inflammatory Response to Cardiac Surgery. Anesthesiology [Internet]. 2002 Jul;97(1):215-52. Available from: https://doi.org/10.1097/00000542-200207000-00030

11. Marik PE, Corwin HL. Acute lung injury following blood transfusion: Expanding the definition. Crit Care Med [Internet]. 2008;36(11):3080-4. Available from: https://doi.org/10.1097/ccm.0b013e31818c3801

12. Roques F, Michel P, Goldstone AR, Nashef SAM. The logistic EuroSCORE. Eur Heart J [Internet]. 2003;24(9):882-3. Available from: https://doi.org/10.1016/S0195-668X(02)00799-6

13. Toumpoulis IK, Anagnostopoulos CE, Swistel DG, DeRose Jr JJ. Does EuroSCORE predict length of stay and specific postoperative complications after cardiac surgery? Eur J Cardio-Thoracic Surg [Internet]. 2005;27(1):128-33. Available from: https://doi.org/10.1016/i.ejcts.2004.09.020

14. Stüber F, Hoeft A. The influence of genomics on outcome after cardiovascular surgery. Curr Opin Anesthesiol [Internet]. 2002;15(1). Available from: https://doi.org/10.1097/00001503-200202000-00002

15. Podgoreanu M V, Schwinn DA. New Paradigms in Cardiovascular Medicine: Emerging Technologies and Practices: Perioperative Genomics. J Am Coll Cardiol [Internet]. 2005;46(11):1965-77. Available from: https://doi.org/10.1016/i.jacc.2005.08.040

16. Kowalik MM, Lango R. Genotype Assessment as a Tool for Improved Risk Prediction in Cardiac Surgery. J Cardiothorac Vasc Anesth [Internet]. 2014;28(1):163-8. Available from: https://doi.org/10.1053/i.jvca.2013.01.002

17. Podgoreanu MV. Inflammatory Gene Polymorphisms and Risk of Postoperative Myocardial Infarction After Cardiac Surgery. Circulation [Internet]. 2006;114(1_suppl):I-275-I-281. Available from: https://doi.org/10.1161/CIRCULATIONAHA.105.001032

18. Stafford-Smith M, Podgoreanu M, Swaminathan M, Phillips-Bute B, Mathew JP, Hauser EH, et al. Association of genetic polymorphisms with risk of renal injury after coronary bypass graft surgery. Am J Kidney Dis [Internet]. 2005;45(3):51930. Available from: https://doi.org/10.1053/j.ajkd.2004.11.021

19. Gaudino M, Di Castelnuovo A, Zamparelli R, Andreotti F, Burzotta F, lacoviello L, et al. Genetic control of postoperative systemic inflammatory reaction and pulmonary and renal complications after coronary artery surgery. J Thorac Cardiovasc Surg [Internet]. 2003;126(4):1107-12. Available from: https://doi.org/10.1016/s0022-5223(03)00396-9

20. Welsby IJ, Podgoreanu M V, Philips-Bute B, Mathew JP, Smith PK, Newman MF, et al. Genetic factors contribute to bleeding after cardiac surgery. J Thromb Haemost [Internet]. 2005;3(6):1206-12. Available from: https://doi.org/10.1111/ j.1538-7836.2005.01337.x 
21. Mathew JP, Podgoreanu M V, Grocott HP, White WD, Morris RW, Stafford-Smith M, et al. Genetic Variants in P-Selectin and C-Reactive Protein Influence Susceptibility to Cognitive Decline After Cardiac Surgery. J Am Coll Cardiol [Internet]. 2007;49(19):1934-42. Available from: https://doi.org/10.1016/i.jacc.2007.01.080

22. Henckaerts L, Nielsen KR, Steffensen R, Van Steen K, Mathieu C, Giulietti A, et al. Polymorphisms in innate immunity genes predispose to bacteremia and death in the medical intensive care unit*. Crit Care Med [Internet]. 2009;37(1):192e3. Available from: https://doi.org/10.1097/ccm.0b013e31819263d8

23. Mølle I, Steffensen R, Thiel S, Peterslund NA. Chemotherapy-related infections in patients with multiple myeloma: associations with mannan-binding lectin genotypes. Eur J Haematol [Internet]. 2006;77(1):19-26. Available from: https://doi. org/10.1111/i.1600-0609.2006.00669.x

24. Thiel S, Steffensen R, Christensen IJ, Ip WK, Lau YL, Reason IJM, et al. Deficiency of mannan-binding lectin associated serine protease-2 due to missense polymorphisms. Genes Immun [Internet]. 2007;8(2):154-63. Available from: https:// doi.org/10.1038/sj.gene.6364373

25. Force* TADT. Acute Respiratory Distress Syndrome: The Berlin Definition. JAMA [Internet]. 2012;307(23):2526-33. Available from: https://doi.org/10.1001/jama.2012.5669

26. Meyer NJ, Garcia JGN. Wading into the Genomic Pool to Unravel Acute Lung Injury Genetics. Proc Am Thorac Soc [Internet]. 2007;4(1):69-76. Available from: https://doi.org/10.1513/pats.200609-157jg

27. Bannerman DD, Goldblum SE. Mechanisms of bacterial lipopolysaccharide-induced endothelial apoptosis. Am J Physiol Cell Mol Physiol [Internet]. 2003;284(6):L899-914. Available from: https://doi.org/10.1152/ajplung.00338.2002

28. Villar J, Pérez-Méndez L, Espinosa E, Flores C, Blanco J, Muriel A, et al. Serum Lipopolysaccharide Binding Protein Levels Predict Severity of Lung Injury and Mortality in Patients with Severe Sepsis. Morty RE, editor. PLoS One [Internet]. 2009;4(8):e6818. Available from: https://doi.org/10.1371/journal.pone.0006818

29. Viladés C, Escoté $X$, López-Dupla M, Martinez E, Domingo P, Asensi V, et al. Involvement of the LPS-LPB-CD14-MD2-TLR4 inflammation pathway in HIV-1/HAART-associated lipodystrophy syndrome (HALS). J Antimicrob Chemother [Internet]. 2014;69(6):1653-9. Available from: https://doi.org/10.1093/jac/dku032

30. Milot J, Perron J, Lacasse Y, Létourneau L, Cartier PC, Maltais F. Incidence and Predictors of ARDS After Cardiac Surgery. Chest [Internet]. 2001;119(3):884-8. Available from: https://doi.org/10.1378/chest.119.3.884

31. Rong LQ, Di Franco A, Gaudino M. Acute respiratory distress syndrome after cardiac surgery. J Thorac Dis. 2016;8(10):E1177-86.

32. Stephens RS, Shah AS, Whitman GJR. Lung Injury and Acute Respiratory Distress Syndrome After Cardiac Surgery. Ann Thorac Surg [Internet]. 2013;95(3):1122-9. Available from: https://doi.org/10.1016/i.athoracsur.2012.10.024

33. Asimakopoulos G, Taylor KM, Smith PL, Ratnatunga CP. Prevalence of acute respiratory distress syndrome after cardiac surgery. J Thorac Cardiovasc Surg [Internet]. 1999 Mar;117(3):620-1. Available from: https://doi.org/10.1016/s0022-5223(99)70348-x

34. Pawlaczyk R, Swietlik D, Lango R, Rogowski J. Off-Pump Coronary Surgery May Reduce Stroke, Respiratory Failure, and Mortality in Octogenarians. Ann Thorac Surg [Internet]. 2012 Jul;94(1):29-37. Available from: https://doi.org/10.1016/i. athoracsur.2012.03.037

35. Rubenfeld GD, Caldwell E, Peabody E, Weaver J, Martin DP, Neff M, et al. Incidence and Outcomes of Acute Lung Injury. N Engl J Med [Internet]. 2005;353(16):1685-93. Available from: https://doi.org/10.1056/NEJMoa050333

36. Rubenfeld GD, Caldwell E, Granton J, Hudson LD, Matthay MA. Interobserver Variability in Applying a Radiographic Definition for ARDS. Chest [Internet]. 1999 Nov;116(5):1347-53. Available from: https://doi.org/10.1378/chest.116.5.1347

37. Meade MO, Cook RJ, Guyatt GH, Groll R, Kachura JR, BEDARD M, et al. Interobserver Variation in Interpreting Chest Radiographs for the Diagnosis of Acute Respiratory Distress Syndrome. Am J Respir Crit Care Med [Internet]. 2000;161(1):8590. Available from: https://doi.org/10.1164/ajrccm.161.1.9809003

38. Chanock SJ, Manolio T, Boehnke M, Boerwinkle E, Hunter DJ, Thomas G, et al. Replicating genotype-phenotype associations. Nature [Internet]. 2007;447(7145):655-60. Available from: https://doi.org/10.1038/447655a 